\title{
Stavovi stručnjaka/inja o politici regulacije prostitucije u Hrvatskoj
}

\author{
RAŠELJKA KRNIĆ \\ Institut društvenih znanosti Ivo Pilar \\ MIRJANA ADAMOVIĆ \\ Institut za društvena istraživanja u Zagrebu \\ IVANA RADAČIĆ \\ Institut društvenih znanosti Ivo Pilar
}

\begin{abstract}
Sažetak
Različite ideološke pozicije određuju modele, odnosno politike usmjerene prema reguliranju prostitucije, tj. prema osobama koje se prostitucijom bave, organiziraju prostituciju ili traže usluge u toj domeni društvenog života. U ovom radu prikazujemo stavove relevantnih stručnjaka/inja o politikama prostitucije u Republici Hrvatskoj. Rezultati rada temelje se na kvalitativnom istraživanju provedenom polustrukturiranim intervjuima na uzorku 15 stručnjaka/inja iz različitih područja (ministarstava, vladinih ureda, neovisnih državnih tijela, saborskih odbora i civilnih udruga) u čijem je djelokrugu regulacije fenomen prostitucije ili s njim povezani problemi. Sugovornici/e prostituciju najčešće smještaju ili u diskurs nasilja i eksploatacije ili u diskurs seksualnog rada. Većina stručnjaka/inja zagovara promjenu modela regulacije prostitucije, a među najčešće spominjanim europskim modelima, na koje bi se hrvatski model mogao ugledati, su švedski model kriminalizacije klijenata, dekriminalizacijski model i model legalizacije. Primjetno je da se stručnjaci/kinje iz civilnog društva koji donose programe smanjenja štete i rade s osobama koje prodaju seksualne usluge češće opredjeljuju za liberalne modele reguliranja prostitucije. Svi stručnjaci/kinje ističu važnost donošenja politika koje bi bile usmjerene prema lakšem izlasku iz prostitucije.
\end{abstract}

Ključne riječi: prostitucija, modeli regulacije prostitucije, javne politike, ljudska prava 


\section{Uvod}

Prostitucija i njezina regulacija još uvijek su tabu teme u hrvatskom društvu. Temelj zakonskih odredbi kojima se regulira prostitucija donesen je još u vrijeme kad je Republika Hrvatska bila dio bivše SFR Jugoslavije, u zakonu koji određuje prekršaje protiv javnog reda i mira, koji je prostituciju definirao kao društveno zlo, a osobe koje se bave prostitucijom kao delinkvente/ice. Unatoč zastarjelosti takvog rješenja i nekompatibilnosti s načelom ravnopravnosti spolova i standardima zaštite ljudskih prava, u Republici Hrvatskoj nije bilo većih (političkih) rasprava o modelima regulacije prostitucije. Nadalje, malo je znanstvenih istraživanja u tom području, a ne postoje ni organizacije za zaštitu prava osoba koje se bave prostitucijom (seksualnih radnica/ka). ${ }^{1}$ Takvo je stanje u suprotnosti s trendovima u zemljama Europske unije, koje u posljednjih dvadesetak godina karakteriziraju promjene politika $\mathrm{i}$ zakonodavstva utemeljene na žustrim raspravama, u kojima ulogu osim političkih aktera imaju i feminističke organizacije i organizacije za zaštitu prava seksualnih radnica/ka (Danna, 2014).

S obzirom na stanje u Hrvatskoj te na nedostatak informacija o stavovima glavnih aktera u donošenju politika regulacije prostitucije, cilj ovog kvalitativnog istraživanja bio je istražiti stavove koji upućuju na rasprave i eventualne promjene o toj temi. Osim uvida u stavove o hrvatskom zakonodavnom modelu i relativno recentnim prijedlozima promjena, zanimalo nas je, kako bismo utvrdile koliko je dominantan diskurs o društvenom zlu uopće prisutan, pitanje do koje mjere su stručnjaci/kinje upoznati s dominantnim raspravama o politikama regulacije prostitucije u Europi, odnosno dominantnim europskim i ostalim modelima. U skladu s takvim interesom formulirale smo glavno istraživačko pitanje koje glasi: kako stručnjaci/kinje percipiraju model regulacije prostitucije u Hrvatskoj u odnosu na dominantne modele regulacije prostitucije u Europskoj uniji i šire te je li potrebna njegova promjena. U poglavljima koja slijede predstavljamo glavne modele regulacije prostitucije, hrvatski regulatorni okvir, metodologiju, raspravu i zaključke.

\section{Modeli zakonske regulacije prostitucije}

Postoje razne ideološke pozicije vezane uz prostituciju (koju ovdje definiramo kao prodaju seksualnih usluga za novac) koje se reflektiraju u politikama i zakonskim modelima regulacije prostitucije. Politike prostitucije većinom se klasificiraju kao politike moralnosti, koje karakterizira to da na njih više utječu ideologija i politika

1 Termin seksualna radnica skovala je krajem 1970-ih aktivistkinja Carole Leigh kako bi se naglasio aspekt rada i radi destigmatizacije (dostupno na: https://www.nswp.org/timeline/event/ carol-leigh-coins-the-term-sex-work, pristupljeno 17. travnja 2021.).S obzirom na to da većina osoba koje prodaju seksualne usluge preferiraju taj termin, njime se koristimo u članku. 
nego činjenice i dokazi (Wagenaar i Altnik, 2012). Uz prostituciju se vežu moralna panika i razni strahovi, pa se o njoj često raspravlja u kontekstu morala i javnog reda i mira te javnog zdravlja (Burchfield, Sample i Lytle, 2014).

U posljednje vrijeme sve se više prepoznaje da su politike regulacije prostitucije (i) politike rodne ravnopravnosti. Naime, fenomen prostitucije rodno je određen ne samo činjenicom da su većina osoba koje prodaju usluge žene, a većina osoba koje ih kupuju muškarci već i time što je seksualnost jedna od ključnih tema rodnog poretka (Outshoorn, 2005). Shodno tome, politike prostitucije već su nekoliko desetljeća predmet interesa feminističkih teorija i aktivizma, što sve više utječe na stvaranje i oblikovanje politika usmjerenih prema regulaciji prostitucije, kako liberalnih na Novom Zelandu tako i radikalno feminističkih u Švedskoj.

Dva su dominantna i po svemu oprečna feministička shvaćanja prostitucije: prvo, radikalno feminističko, koje prostituciju smatra nasiljem nad ženama (Barry, 1996; Jeffreys, 2008) i seksualnim iskorištavanjem u uvjetima patrijarhata, i drugo, liberalno, koje prostituciju smatra radom, a pojedine aktere prostitucije racionalnim i aktivnim osobama koje se ponašaju u skladu s osobnim izborima na autonoman način (Valadier, 2018). Osim tog dihotomnog shvaćanja prostitucije postoji i treći feministički pristup (pretežno iz postmoderne perspektive) utemeljen na empirijskim istraživanjima, koji prepoznaje pravo osoba koje prodaju seksualne usluge na samoodređenje, kao i društvene, ekonomske i političke prepreke slobodi, ne ulazeći u vrijednosno određenje prostitucije kao inherentno opresivne ili kao primjer seksualnih sloboda (Radačić i Pajnik, 2017; Della Giusta i Munro, 2016; Scoular, 2010; Sanders, 2006; O’Neil, 2001; O’Connell Davidson, 1998). Također je sve više relevantan diskurs prava seksualnih radnica/ka, koji prostituciju smatra legitimnim radom, a bilo koji oblik kriminalizacije kršenjem njihovih ljudskih prava (McClintock, 1993).

Ideološke pozicije o prostituciji reflektiraju se u politikama regulacije prostitucije u raznim društveno-političkim kontekstima kroz povijest. Historijski, modeli su klasificirani kao: prohibicionistički (utemeljen na stajalištu da je prostitucija nemoralna, kažnjavaju se i prodavatelj/ica i kupac seksualne usluge), regulacionistički (smatra prostituciju neophodnim društvenim zlom, usmjeren je prvenstveno na kontrolu zaštite javnog zdravlja) i abolicionistički (smatra da su razne mjere kontrole usmjerene protiv žena, usmjeren je na liberalizaciju prostitucije, ali i kažnjavanje trećih strana) (Danna, 2014). Tim klasičnim modelima koji su prevladavali u 20. stoljeću pridružili su se novi: neoprohibitizam (kažnjavanje klijenata) i neoregulacionizam (legalizacija prostitucije) (ibid.).

Danas je uobičajena klasifikacija na modele kriminalizacije, legalizacije i dekriminalizacije (Abel i Fitzgerald, 2010; Mossman, 2007), s time da se prema nekim modelima kriminalizacije kažnjavaju sve strane, prema nekima treće strane 
(organizatori), neki kažnjavaju osobe koje prodaju seksualne usluge (i treće strane), a neki klijente (i treće strane). Ti su modeli idealni koncepti jer su u praksi kombinacija različitih idealnih tipova. Osim toga, različiti modeli imaju slične učinke jer se koriste u odnosu na određene aspekte prostitucije - npr. uličnu, koja se doživljava kao prijetnja javnom redu i miru (Scoular, 2010). Svim je modelima zajedničko da imaju implikacije na ljudska prava osoba koje prodaju seksualne usluge.

Jedan od dominantnih modela u Europskoj uniji jest model kažnjavanja klijenata, koji se često naziva i švedski ${ }^{2}$ jer ga je Švedska prva uvela 1999. godine. Taj model preferira i EU Parlament, koji je 2014. godine donio rezoluciju prema kojoj se pitanje prostitucije, kao globalnog fenomena, treba promatrati u okviru politika rodne ravnopravnosti (Deana, 2019). Model počiva na tri glavne pretpostavke: kriminalizaciji kupaca seksualnih usluga, dekriminalizaciji osoba koje se bave prostitucijom i državnim politikama koje podržavaju lakši izlazak iz prostitucije. Taj se pristup prostituciji podudara s radikalno feminističkim, a s aspekta javnih politika neoabolicionističkim, zbog stava kako je prostitucija nasilje muškaraca nad ženama s obzirom na to da su klijenti seksualnih radnica većinom muškarci (Kingston i Thomas, 2018). On se zasniva i na pretpostavci kako žene najčešće ulaze u prostituciju zbog nepovoljnih životnih okolnosti (zlostavljanje u djetinjstvu, siromaštvo, prisila itd.), a manje svojevoljno. Model počiva na holističkom pristupu, koji podrazumijeva punu potporu osobama koje žele izaći iz prostitucije, javne kampanje protiv prostitucije, edukacijske programe u školama, dodatno obrazovanje policije, sudova, socijalnih službi i sl. ${ }^{3}$ Međutim, potpora za izlazak iz prostitucije je u primjeni modela u Švedskoj i nekim drugim zemljama (npr. Francuska), čini se, najviše zakazala (Burnett, 2021). Između ostaloga, primijećeno je da osobe involvirane u prostituciju imaju fluidan odnos prema prostituciji, ovisan o drugim radnim opcijama koje su im na raspolaganju, te da je na državnoj razini potrebno ulagati više financijskih sredstava kako bi se osobama koje se bave prostitucijom pomoglo $\mathrm{u}$ izlasku iz prostitucije s obzirom na izrazito prisutnu stigmatizaciju prilikom toga procesa (Jacobsson, 2012).

Osim toga, upozorava se da model nije ostvario svoje ciljeve koji se odnose na smanjivanje trgovanja ljudima i rodne nejednakosti (Kingston i Thomas, 2018). Istraživanja ukazuju na nedostatke modela s obzirom na iskustva u praksi, jedan od njih je kažnjavanje klijenata, što povećava rizik za osobe koje prodaju seksualne usluge jer moraju brže ugovarati usluge zbog straha od policije (Levy i Jakobsson, 2014); k tome dovodi do povećanja nasilja prema osobama koje prodaju seksual-

${ }^{2}$ Naziva se još Nordijski, Sex Buyers Law, Abolitionist i Equality model. Uz neke preinake implementiran je i u Norveškoj, djelomično u Finskoj i Islandu, Sjevernoj Irskoj, Irskoj, Francuskoj i Izraelu.

3 Vidjeti više na: https://nordicmodelnow.org/what-is-the-nordic-model/. 
ne usluge i do pritiska da prihvate različite seksualne zahtjeve (Le Bail, Giametta i Rassouw, 2016) te kriminalizacija klijenata pospješuje premještanje seksualne industrije u ilegalnu sferu (Burnett, 2021; Pro Sentret, 2012, prema Kingston i Thomas, 2018). Problem je i u tome što je nordijski model uvelike zastario. Implementiran je na pretpostavci dominacije ulične prostitucije koja se u međuvremenu, zahvaljujući razvoju komunikacije internetom, izmjestila u zatvorene prostore. Time je mogućnost kontrole prostitucije značajno pala, a s obzirom na promijenjene odnose moći između osoba koje prodaju i osoba koje naručuju seksualne usluge, došlo je i do promjene strukture klijenata, odnosno povećanja broja naručitelja seksualnih usluga koji i inače imaju problema sa zakonom (Burnett, 2021).

Drugi model dominantan u Europi, koji se primjenjuje u Njemačkoj i Nizozemskoj, jest legalizacija prostitucije. Počiva na pretpostavci poštivanja individualne slobode, slobode izbora te neutralnosti države u pogledu osobnog morala (Post i sur., 2019). Iako je takvim modelom sve u vezi s prostitucijom naizgled liberalizirano, pojedini autori upozoravaju da do liberalizacije uistinu nije došlo. Naime, prostitucija se smatra poslom koji treba biti reguliran sličnim standardima kao i svaki drugi (radni sati, zdravstveno i mirovinsko osiguranje, bolovanje itd.) (Aronowitz, 2014), a istovremeno se smatra specifičnim i neuobičajenim načinom zarađivanja za život čije je prakticiranje vezano uz politike smanjenja štete i zaštite javnog zdravlja te zdravlja osoba koje se prostitucijom bave (Aronowitz, 2014; Weitzer, 2012). Pojedine države u kojima se primjenjuje taj model postavljaju uvjete kao što su obavezna registracija osoba koje se bave prostitucijom te obavezni zdravstveni pregledi ili testiranja na HIV, što je sve upitno iz perspektive zaštite ljudskih prava (Sex Worker Forum, 2017; Overs i Loff, 2013). Osim toga, s obzirom na razna ograničenja, uključujući ona vezana uz zabranu rada nedržavljana EU, velik dio industrije radi ilegalno. Nadalje, legalizacija nije ukinula problem nedobrovoljne prostitucije. Na primjer, izvještaji o stanju u Nizozemskoj upućuju na prisustvo nedobrovoljne prostitucije i seksualne eksploatacije te na promjenu javnog imidža osoba koje se bave prostitucijom od neovisnih u žrtve eksploatacije i nasilja (Daalder, 2007; Post i sur., 2019).

Treći model, koji u osnovi dekriminalizira prostituciju, prakticira Novi Zeland, a uveden je i u australskoj državi New South Wales (Aronowitz, 2014; Weitzer, 2012). Taj model također smatra prostituciju radom, no za razliku od legalizacijskog ima manje ograničenja, koja su prvenstveno usmjerena na zaštitu ljudskih prava seksualnih radnica/ka. Namjera tog modela, kada je 2003. godine uveden na Novom Zelandu na poticaj udruge seksualnih radnica/ka u suradnji s feminističkim organizacijama i nezavisnim članom parlamenta, bila je, između ostaloga, smanjiti viktimizaciju i eksploataciju, eliminirati maloljetničku prostituciju, smanjiti kriminal vezan uz prostituciju, smanjiti broj ilegalnih imigranata i suzbiti trgovanje 
ljudima (Weitzer, 2012). Novozelandski model naziva se minimalističko-legalizacijskim jer postavlja puno manje ograničenja vezanih uz legalizaciju posla (ibid.). Zakonske odredbe usmjerene su prvenstveno na zaštitu seksualnih radnica/ka od eksploatacije te utječu na njihovu dobrobit, sigurnost i zdravlje, a i na javno zdravlje (Ostergren, 2017; Aronowitz, 2014; Abel i Fitzgerald, 2012). Evaluacije primjene zakona pokazale su da su se životni uvjeti seksualnih radnica/ka znatno popravili (Aronowitz, 2014) te da se poboljšao odnos seksualnih radnica/ka s policijom (Armstrong, 2018). Također, došlo je do pada nasilja prema seksualnim radnicama/ima koje/i od početka primjene dekriminalizacije većinom rade u zatvorenim prostorima (Weitzer, 2012). Na uspjeh tog modela zasigurno je utjecalo to što politički akteri od početka surađuju s udrugom seksualnih radnica/ka (New Zealand Prostitute Collective - NZPC) te uvažavaju njihovo mišljenje (Ostergren, 2017; Radačić, 2017c), čemu zasigurno doprinosi neposredan svakodnevni kontakt NZPC-a sa seksualnim radnicama/ima te ukupna briga oko realizacije njihovih ljudskih prava (Radačić, 2017c). Unatoč svemu, nije došlo do destigmatizacije seksualnih radnica/ka u većoj mjeri, javna podrška tome modelu je nestalna i još uvijek je prisutan nelegalni, seksualni rad različitih skupina koje se ne žele registrirati u sustav (Harrington, 2012).

Sva tri danas dominantna modela regulacije prostitucije - kažnjavanje klijenata, legalizacija i dekriminalizacija - osmišljena su radi zaštite (u različitoj mjeri i s različite pozicije) ljudskih prava osoba koje prodaju seksualne usluge te nijedan ne predviđa njihovo kažnjavanje. Kažnjavanje osoba koje prodaju seksualne usluge u suprotnosti je s međunarodnim standardima zaštite ljudskih prava (UN Working Group on Discrimination against Women and Girls, 2016, 2018; Specijalni izvjestitelj o pravu na zdravlje, 2010). Unatoč tome, u većini država centralne i istočne Europe te centralne Azije, kojima je zajedničko tzv. "socijalističko" naslijeđe shvaćanja prostitucije kao nemoralne i neproduktivne aktivnosti, prodaja seksualnih usluga smatra se prekršajem protiv javnog reda i mira (SWAN, 2019). U taj krug spada i Republika Hrvatska.

\section{Hrvatski model regulacije prostitucije}

Hrvatski model utemeljen je na socijalističkom poimanju prostitucije kao ostatka buržoaskog društva koji treba iskorijeniti (Radulović, 1986). Temeljni zakon, prema kojem se vodi najviše predmeta, ${ }^{4}$ jest Zakon o prekršajima protiv javnog reda $\mathrm{i}$ mira (ZPJRM), koji je donesen 1977. (NN 41/77), a u hrvatsko je zakonodavstvo, s manjim izmjenama, preuzet 1990. godine (NN 47/90, 55/91, 29/94). Zakon propi-

${ }^{4}$ U razdoblju od 2014. do 2019. zabilježen je 141 prekršajni postupak te 4 kaznena predmeta na sudu u Zagrebu i Splitu. 
suje dva prekršaja: osoba koja dopušta da se u njezinoj prostoriji vrši bludničenje ili na drugi način pomaže vršenju prostitucije kažnjava se novčanom kaznom od 50 do 350 ondašnjih njemačkih maraka (DEM) ili kaznom zatvora do 30 dana (čl. 7.), a osoba koja se odaje prostituciji kažnjava se novčanom kaznom od 50 do 200 DEM ili kaznom zatvora do 30 dana (čl. 12.). Pored toga, osobi koja izvrši prekršaj iz čl. 12. ZPJRM mogu se izreći dvije zaštitne mjere - obavezno liječenje od AIDS-a i spolnih bolesti te udaljenje iz općine u kojoj je prekršaj počinjen (čl. 34. i čl. 36.). Istraživanje sudske prakse pokazuje da predmeta po čl. 7. posljednjih godina gotovo i nema, a da u policijskoj i sudskoj praksi postoje neusklađenosti sa standardima zaštite ljudskih prava (Radačić, 2017a, 2017b; Radačić i Antić, 2021).

Kazneni zakon kriminalizira djela povezana s prostitucijom u glavi XVI. koja se odnosi na kaznena djela protiv spolne slobode. ${ }^{5}$ Osnovni oblik kaznenog djela "prostitucija" podrazumijeva namamljivanje, vrbovanje ili poticanje druge osobe na pružanje spolnih usluga radi zarade ili druge koristi ili organiziranje ili omogućavanje drugoj osobi pružanje spolnih usluga, dok kvalificirani oblik pretpostavlja određeni oblik prisile (sila, prijetnja, prijevara, obmana, zloupotreba ovlasti ili teškog položaja ili odnosa zavisnosti), a kažnjivo je i korištenje usluga prisiljenih osoba (ako je osoba znala i morala znati), kao i oglašavanje prostitucije (čl. 157.). Podvođenje maloljetnih osoba, klasificirano kao kazneno djelo spolnog zlostavljanja i iskorištavanja djeteta, definirano je na sličan način, $s$ time da su predviđene veće kazne, a također se kažnjavaju klijenti maloljetnih osoba ako su za tu činjenicu znali ili su morali znati (čl. 162.).

Ministarstvo unutarnjih poslova prvi je puta 2012. godine iznijelo prijedlog kriminalizacije klijenata u svim slučajevima, smatrajući da će ona imati preventivnu funkciju te odaslati poruku o odgovornosti (i) klijenata. No, za razliku od švedskog modela, prema tom prijedlogu ne bi se prekršajno gonili samo klijenti, već bi se nastavilo prekršajno goniti i osobe koje prodaju usluge, s time da bi se odgovornost proširila eksplicitno i na nuđenje usluga u javnom prostoru te bi se značajno povećale kazne: nuđenje (i traženje) seksualnih usluga u javnosti kažnjavalo bi se novčanom kaznom od 1.000 do $5.000 \mathrm{kn}$ ili 30 dana zatvora, dok bi se prodaja i kupnja kažnjavale novčanom kaznom od 4.000 do 100.000 ili 60 dana zatvora. ${ }^{6}$ Taj prijedlog na kraju nije stavljen na javnu raspravu jer mu se protivio tadašnji premijer (Jutarnji list, 2012) pa je ponovljen 2016., ali nije raspravljan u Saboru, iako je prošao javnu raspravu, s obzirom na to da je pala Vlada.

5 Čl. 175. Kaznenog zakona, Narodne novine, br. 125/11 i 144/12, 56/15 i 61/15, 101/17, 118/18, $126 / 19$.

6 Prema istraživanju sudske prakse na sudovima u Zagrebu, Splitu i Rijeci kazne su bile u rasponu od 110 do 750 kn (Radačić i Antić, 2021). 
Prostitucija u Hrvatskoj kao takva nije predmet posebnih javnih politika ni strateških dokumenata, iako se ta tema indirektno najčešće razmatra u kontekstu kriminalnih aktivnosti vezanih uz trgovanje ljudima. Analiza glavnih okvira javnih politika (Šipić, Radačić i Baketa, 2021) pokazuje kako se prostitucija pojavljuje u pet diskurzivnih okvira: javnog reda i mira, zaštite spolnih sloboda, javno-zdravstvene prijetnje, rodno uvjetovanog nasilja i seksualnog rada. Okvir javnog reda i mira prostituciju tretira redukcionistički jer se uopće ne prepoznaju problemi eksploatacije i rodne i višestruke diskriminacije niti se propituju učinci kriminalizacije na prava osoba koje prodaju seksualne usluge. Rodna dimenzija problema i rješenja nije obrađena u okviru zaštite spolnih sloboda prisutnom u Kaznenom zakonu, a nisu razmatrani ni učinci kriminalizacije dobrovoljne organizacije prostitucije. Aktere koji problematiziraju zakonski model autori nalaze s jedne strane u neovisnom tijelu koje se bavi rodnom diskriminacijom (Pravobraniteljica za ravnopravnost spolova), a s druge u civilnom sektoru, koji predlaže različita rješenja: kažnjavanje klijenata ili dekriminalizaciju ovisno o diskurzivnim okvirima kojima se koriste (rodno uvjetovanog nasilja i seksualnog rada). Okvir seksualnog rada prisutan je samo u udrugama koje se bave smanjenjem štete, a koje inzistiraju na važnosti uključivanja osoba koje prodaju seksualne usluge u donošenje javnih politika. Ostala tri spomenuta okvira prostituciju smatraju problemom koji nema rodnu vrijednosnu komponentu jer se promatra s jedne strane kao prijetnja javnom redu i miru, a s druge kao potreba zaštite spolnih sloboda i javnog zdravlja.

\section{Metodologija}

U ovom se istraživanju kvalitativnim pristupom željelo dobiti uvide u mišljenja i stavove relevantnih stručnjaka na razini javnih politika o fenomenu prostitucije, hrvatskom regulatornom modelu te suvremenim modelima regulacije u svijetu. ${ }^{7}$ Podaci su prikupljeni metodom polustrukturiranog intervjua na namjernom uzorku od 15 stručnjaka/inja, uz tehniku varijacije na razini sudjelovanja u kreiranju javnih politika, pri čemu je osnovni kriterij bila pretpostavka o znanju ili iskustvu u radu vezanom uz politike koje se direktno ili indirektno tiču fenomena prostitucije. Prema tako postavljenom kriteriju u uzorak su ušla ministarstava, vladini uredi, saborski odbori, neovisne državne institucije i udruge civilnog društva.

Planirani uzorak uključivao je stručnjake/inje iz relevantnih ministarstava (Ministarstvo pravosuđa, Ministarstvo unutarnjih poslova, Ministarstvo za demografiju, obitelj, mlade i socijalnu politiku, Ministarstvo zdravstva), neovisnih institucija za zaštitu ljudskih prava (Pučka pravobraniteljica, Pravobraniteljica za ravnoprav-

${ }^{7}$ Ovo je istraživanje dio projekta Regulacija prostitucije u Hrvatskoj, koji financira Hrvatska zaklada za znanost projektom IP-2018-01-3878. 
Tablica 1. Sastav uzorka

\begin{tabular}{|l|c|}
\hline Institucije & N \\
\hline Udruge civilnog društva & 6 \\
\hline Ministarstva & 4 \\
\hline Neovisne nacionalne institucije & 3 \\
\hline Odbor Hrvatskog sabora & 1 \\
\hline Ured Vlade RH & 1 \\
\hline Ukupno & 15 \\
\hline
\end{tabular}

nost spolova, Pravobraniteljica za djecu), jednog od relevantnih saborskih odbora, Ureda za ljudska prava i prava nacionalnih manjina RH te relevantnih udruga (udruge za ljudska prava, udruge koje se bave nasiljem nad ženama te udruge koje rade direktno s određenom populacijom osoba koje prodaju seksualne usluge) (tablica 1).

Pojedinim stručnjacima/kinjama bilo je neugodno govoriti o predloženoj temi, a stručnjaci/kinje iz pojedinih organizacija civilnog društva te državnih institucija odbili su i/ili dugotrajno odgađali intervjuiranje, što je, s obzirom na planiranu izvedbu istraživanja, onemogućilo intervjuiranje. Svima intervjuiranima ponuđeno je da se o temi izjasne anonimno, a pojedini stručnjaci/kinje to su i zahtijevali, ali većina je bila suglasna da se navede institucija u kojoj rade. Intervjui su provedeni od svibnja do rujna 2020. godine. Trajali su u prosjeku između pola sata i sat vremena, a provele su ih četiri istraživačice. Intervjui su transkribirani te analizirani primjenom tematske analize (Boyatzis, 1998) u programu NVivo 12. Postupak kodiranja bio je induktivnog karaktera; prvo su konstruirani deskriptivni kodovi, a potom se pristupilo njihovoj sistematizaciji te kritičkoj interpretaciji (Terry i sur., 2017).

Sugovornicima/ama su postavljena sljedeća pitanja: 1. Jesu li stručnjaci/kinje upoznati sa zakonskim rješenjima regulacije prostitucije i što misle o njima? 2. Smatraju li da treba kažnjavati osobe koje se bave prostitucijom? 3. Jesu li upoznati s pokušajima izmjena prekršajnih odredaba o prostituciji? 4. Jesu li upoznati s drugim modelima regulacije prostitucije i što misle o njima? 5. Na čemu bi se trebala temeljiti javna politika i tko bi sve trebao biti uključen u donošenje javnih politika? 6. Trebaju li i osobe koje se bave prostitucijom biti uključene u procese donošenja javnih politika? U skladu s tako postavljenim pitanjima kodiranjem smo dobili tri tematske cjeline prema kojima nadalje i izlažemo rezultate rada. 


\section{Rezultati}

\subsection{Kritičko sagledavanje zakonodavnog okvira i javnih politika}

Ispitanike smo pitali za mišljenje o postojećim zakonskim rješenjima u Hrvatskoj te treba li kažnjavati osobe koje se bave prostitucijom. Iskazani stavovi jasno pokazuju kako su stručnjaci, neovisno o razlozima takvih stavova, izrazito kritični prema sadašnjem zakonu koji, smatraju svi, treba što prije mijenjati. Tri citata koja slijede ilustriraju stav kako je promjena sadašnjeg zakona nužna zbog izrazito osjetljivog i ugroženog položaja osoba koje pružaju seksualne usluge. Sadašnji zakon koji ih kriminalizira na taj ih način samo dodatno ugrožava i čini ranjivima, a to je, smatraju stručnjaci/kinje, neprihvatljivo.

Ja osobno ne bih kažnjavala osobe koje se bave prostitucijom. Mislim da ih se time gura u dvostruko nepovoljniji položaj. (Ured pučke pravobraniteljice)

Naime, protivimo se izričito kažnjavanju osoba koje se bave prostitucijom, budući da je riječ o socijalno izrazito ugroženoj skupini kojoj je prvenstveno potrebna društvena podrška, a ne prekršajno gonjenje, stigma i osuda. (Pravobraniteljica za djecu)

Takav način kaznenog, prekršajnog zakonodavstva je zastario. Dakle, ono nasljeđuje taj patrijarhalni obrazac, društveni stereotip koji žene dovodi u nepovoljniji položaj u odnosu na muškarce. (Pravobraniteljica za ravnopravnost spolova)

Seksualne radnice privođene tijekom policijskih racija u iznimno su ranjivoj poziciji, upozorava i sugovornica iz udruge LET, koja iz vlastitog iskustva rada $\mathrm{s}$ tom skupinom i istraživanja koje je udruga provodila ima uvid u različita iskustva koja one doživljavaju tijekom ispitivanja, privođenja i sudskih procesa. Naglašava kako se seksualne radnice osjećaju vrlo ranjivo u odnosu na policajce koji su im katkad i sami klijenti, a na prekršajnim sudovima nerijetko bivaju ponižene i tretirane nekorektno.

Pa ono, kadija te tuži, kadija ti sudi. Tako da mi se taj dio ne sviđa, ne sviđa mi se dio pristupa suda prema njima, to na prekršajnom sudu pretpostavljam baš nije ugodno, to je jednostavno licemjeran odnos. Dakle ono, ujutro crkva, popodne klijent. (LET)

Nadalje, još jedan od razloga zbog kojeg je zakon koji kriminalizira odavanje prostituciji loš, navodi stručnjakinja iz Kuće ljudskih prava, taj je što ne pravi nikakvu distinkciju između žena i muškaraca koji se, barem prema njihovim izjavama, bave tim poslom dobrovoljno i onih za koje se uspostavi istragom da su bili pod nekom vrstom prisile. Sugovornica iz Instituta Pula naglašava uzaludnost kažnjavanja osoba koje pružaju seksualne usluge, pogotovo ako je to jedina mjera koja se 
primjenjuje. Upozorava na otežavanje njihovog ionako teškog položaja dodatnom stigmatizacijom koju sa sobom nosi kriminalizacija.

Mislim da je kažnjavanje samo osobe koja je pružateljica ili pružatelj usluga čista bedastoća. To je još dodatno marginaliziranje te osobe, jer ona je bad guy jer se kurva, a on je super tip jer ju je iznajmio... evo, mojim rječnikom. Tako da mislim da je to sve užasno glupo. A ništa od svega toga po meni nema apsolutno nikakvu svrhu, ako se paralelno s penalom nije osmislio i model rješavanja tog problema. (Institut Pula)

Slično navodi i sugovornica iz jednog saborskog odbora:

... to [kažnjavanje isključivo pružatelja seksualnih usluga] smatram jako lošim jer, dakle, to je ono što i omogućava nastavak te prostitucije i stavlja cijeli teret zapravo na osobu, odnosno na prostitutku koja je često i žrtva u svemu tome.

Razlozi koje stručnjaci/kinje iz različitih domena navode kao one zbog kojih je nužno mijenjati trenutačni zakon (koji kriminalizira seksualni rad, ali uopće ne tereti korisnike seksualnih usluga) brojni su i pripadaju različitim dimenzijama problema. Činjenica je, naglašava sugovornik iz Ministarstva unutarnjih poslova, da se radi o neprecizno formuliranom zakonu u kojem nije do kraja jasno što je to točno prekršajno djelo u kontekstu odavanja prostituciji. To se reflektira i u načinu postupanja policije i sudova koji nije konzistentan, što je očito iz analize sudskih spisa prikupljenih na sudovima u Splitu, Zagrebu i Rijeci (Radačić i Antić, 2021).

Ovaj Zakon o prekršaju protiv javnog reda i mira treba promijeniti, pogotovo taj čl. 12. gdje bi bilo preciznije propisano ono što se inkriminira. Za sada ovo što je propisano, to je neminovno i mi kao policija moramo po tome postupati, a kada razgovaramo o sadašnjim propisima, onda to barem treba decidiranije, odnosno preciznije propisati kako bi se znalo točno što ta radnja znači, da se zna točno koja je to radnja koja je zabranjena. (MUP)

Zaključno, svi su stručnjaci/kinje upoznati sa Zakonom o prekršajima protiv javnog rada i mira koji je na snazi te na njega gledaju izrazito kritično, bez obzira na različite ideje o tome koji bi bio najučinkovitiji pristup regulaciji. Bez obzira na stav o smjeru u kojem bi neki budući zakon trebao ići, većina se ispitanika/ca slaže oko toga da su u kontekstu prostitucije seksualne radnice/i na ovaj ili onaj način stigmatizirane, marginalizirane i stavljene $u$ ranjivu poziciju te ih iz tog razloga ne bi trebalo dodatno kažnjavati. Hrvatske zakone stručnjaci/kinje uglavnom smatraju zastarjelim, a gotovo svi s kojima smo razgovarali najveći problem vide u kriminalizaciji seksualnih radnica, tj. posljedicama koje na te osobe ostavlja takav zakonski okvir.

Svi su naši sugovornici/e bili upoznati i s prijedlozima izmjena Zakona o prekršajima protiv javnog reda i mira iznesenim 2012. i 2016. godine koji su, uz dosa- 
dašnje kažnjavanje nuditelja seksualnih usluga, uključivali i kažnjavanje klijenata te proširivali odgovornost seksualnih radnica. Međutim, ta je vrsta kompromisa, prema kojem se kriminaliziraju i seksualne radnice i klijenti, većini ispitanika/ca neprihvatljiva jer bi takav zakon i dalje bio restriktivan i konzervativan.

Sugovornica iz Ureda pučke pravobraniteljice navodi kako je takav zakon neodređen:

Sustav je nekako pomalo šizofren, u smislu... ideja je bila da se nekako kažnjava i korisnike usluga, ali i pružateljice usluga... Nije klasičan sustav u kojem se samo kažnjavaju klijenti, ali nije ni sustav liberaliziran na način da nisu kažnjavane žene ili bilo tko tko pruža uslugu. (Ured pučke pravobraniteljice)

Takvo zakonsko rješenje problematičnim smatra i Pravobraniteljica za ravnopravnost spolova, koja zastupa “švedski model” regulacije. Navodi kako osoba koja nudi seksualne usluge ni u kom slučaju ne bi smjela biti stavljena u isti položaj kao ona koju takvu uslugu traži:

Važno je reći da je u takvom načinu, takvom odnosu prekršajne odgovornosti, prekršajno pravnih sankcija korisnika, a ne samo pružatelja usluga, nešto što u stvari i ne ide puno u korist same žrtve, jer žrtva je stavljena u isti rang. Dakle, na jednak način se sankcionira i ima to breme odgovornosti kao i onaj koji je u stvari tražitelj, korisnik, koji potiče i održava taj sustav na tržištu odavanja prostituciji. To je ono o čemu sam na početku govorila, dakle njih dvoje su u istom rangu, a zna se $u$ startu tko je tu žrtva. (Pravobraniteljica za ravnopravnost spolova)

Premda zastupa drugačije zakonsko rješenje od Pravobraniteljice za ravnopravnost spolova, sugovornica iz udruge HELP također nije zadovoljna ponuđenim prijedlozima izmjene zakona jer se njima nije odustalo od penaliziranja, već se pojačava kriminalizacija klijenata i još su rigoroznije novčane i zatvorske kazne za pružatelje seksualnih usluga:

Ja ne bih kriminalizirala ni jedne ni druge. Prema tome, definitivno se ne slažem s tim prijedlozima, jer prostitucije je uvijek bilo i uvijek će je biti. (HELP)

S nešto je pak drugačije pozicije o tom prijedlogu izmjene zakona nastupio sugovornik iz Ministarstva unutarnjih poslova. Iako nije iznio jasno mišljenje o tome treba li ili ne treba kažnjavati osobe koje prodaju seksualne usluge, prijedlog izmjena iz 2012. i 2016. godine smatra problematičnim iz perspektive eventualnog sudskog procesa, i to zbog problema koji bi, kažnjavanjem i tražitelja seksualnih usluga, nastali tijekom dokaznog postupka:

S našeg policijskog stajališta, mi smo već tada bili svjesni da će to još teže biti dokazivo. Zamislite koga vi imate kao mogućeg svjedoka za to - nikog. Jer i jedan i 
drugi imaju pravo lagati da bi štitili sebe na sudu. I još bi teže bilo dokazivo. (Ministarstvo unutarnjih poslova)

Zaključno, većina sugovornika ne podržava predložene izmjene zakona koje tumače kao izrazito nepovoljne za osobe koje se bave prostitucijom. Međutim, bez obzira na suglasje koje prevladava u stavovima oko tih do sada predloženih izmjena zakona, vidljivo je da predstavnici različitih institucija takve izmjene ne bi podržali iz različitih razloga.

\subsection{Upoznatost s drugim modelima prostitucije i njihova evaluacija}

S našim ispitanicima/ama razgovarali smo i o njihovom viđenju ostalih dominantnih regulatornih modela. Kao što je već rečeno, radi se o modelu legalizacije, modelu kriminalizacije klijenata i modelu potpune dekriminalizacije dobrovoljne prostitucije odraslih osoba. Zanimalo nas je i kako vide potencijalno rješenje u vidu zakonskog okvira koji bi regulirao prostituciju u Hrvatskoj. Većina sugovornika/ca unaprijed je bila upoznata s osnovnim odrednicama pojedinih modela, ali nisu imali detaljnije informacije o primjeni u praksi, a onima koji nisu bili upoznati ponuđeno je dodatno objašnjenje. Među sugovornicima/ama nailazimo na različite grupe mišljenja i različite razine argumentacije stavova koji, kao i prethodni odgovori, ovise o njihovom viđenju prostitucije. To je pak viđenje katkad utemeljeno na direktnom kontaktu s osobama koje prodaju seksualne usluge, kao u slučaju udruga koje rade programe smanjenja štete, i njihovom profesionalnom ulogom, posebice kad se radi o institucijama ili organizacijama koje se bave rodnom ravnopravnošću, a katkad na čisto osobnim stavovima, u kojem slučaju su odgovori manje decidirani. Tako npr. sugovornica iz udruge LET smatra kako je "novozelandski model" najbolji, izuzev činjenice da dozvole ne mogu dobiti zainteresirane seksualne radnice/i s okolnih otočja, već samo građani i građanke Novog Zelanda, što je, objašnjava, kompromis koji je napravljen pri donošenju zakona da bi se zadovoljio konzervativni dio javnosti i politike. Brojnim primjerima i argumentima obrazlaže kritiku tzv. "švedskog modela" koji se, prema njenim saznanjima, nije pokazao naročito učinkovitim:

Probali su uvjeriti pola Europe u to [da je švedski model najbolji], ali, recimo, ono što se otkrilo u istraživanjima je da su se jednostavno seksualne radnice i klijenti za njima preselili na sjever Švedske gdje je manje policije i takve kontrole... Velik broj seksualnih radnica otišao je i u Dansku i za njima klijenti, pa se kod njih povećao broj. Nema granica, samo most $i$ to je to. (LET)

Nadalje, smatra da ni legalizacija, poput one u Nizozemskoj, nije optimalna zbog brojnih problema koje generira. Napominje kako je ondje legalizacija prisutna samo "na papiru" jer svaka lokalna vlast ima pravo određivati koliko dozvola će 
biti izdano, a broj dozvola se sve više smanjuje; k tome porezna uprava vrši stroge kontrole i stavlja seksualne radnice pod veliku količinu pritiska.

O saznanjima vezanim za problematične aspekte legalizacije u kontekstu Nizozemske govori i sugovornica iz udruge HELP:

I ono što je zanimljivo, baš prošle zime sam srela kolegicu iz Amsterdama i rekla mi je da zapravo oni počinju razmišljati o ponovnoj kriminalizaciji prostitucije. Odnosno o ukidanju legalizacije, jer cilj legalizacije je bio postići što manje crnog tržišta, znači osigurati zdravstveno osiguranje... i na kraju... to se nije postiglo jer i unatoč legalizaciji kod njih nije nikada prestala stigmatizacija. Osobe koje su se bavile prostitucijom odbijale su da im u radnoj knjižici piše da im je posao prostitucija. Također, imate one brodove u Utrechtu gdje je na svakom brodu od 10 prostitutki samo jedna legalna. (HELP)

Nadalje, stručnjakinja također naglašava kako "švedski model" nije rješenje jer penalizaciju bilo koga, osim ako se ne radi o prisili, vidi kao zadiranje u ljudska prava, što uključuje i pravo na izbor bilo koje vrste posla, pa tako i prostitucije.

U skladu sa stavovima ostalih predstavnica harm reduction udruga, novozelandski model podržava, a švedski kritizira i stručnjakinja iz udruge TERRA. Prema njenim riječima, novozelandski model najbolje štiti osobe koje se bave seksualnim radom, a švedski ih dodatno viktimizira.

Čak nije u redu da se kao u Švedskoj kažnjavaju samo klijenti, jer navodno onda se žene opet dovode u položaj da se osjećaju kao da su žrtve. Jer ako se klijent kazni, onda su one žrtve negdje u sebi. (TERRA)

Prema "švedskom modelu" skeptičan je i sugovornik iz Ministarstva unutarnjih poslova, koji pokazuje velik interes za temu te shodno tome i sam istražuje razna rješenja pozivajući se na podatke s neimenovanog portala koji ukazuju na to da taj model nije polučio očekivane rezultate u smislu da brojke ne pokazuju smanjenje prostitucije ni redukciju nasilja prema osobama koje pružaju seksualne usluge. Također ističe problem dokazivanja kaznenog dijela:

Zamislite koji je pritisak da bi vi tu dokazali neko djelo toga davatelja usluga, da bi korisnik bio optužen. Netko mora biti svjedok u tom postupku. Ono što su htjeli s tim postići u Francuskoj i Švedskoj navodno se nije postiglo. (MUP)

I sugovornik iz Ministarstva unutarnjih poslova i sugovornica iz udruge LET naglašavaju kako je za kreiranje nekog novog zakonskog okvira koji bi regulirao taj društveni fenomen u našem kontekstu potrebno provesti niz istraživanja iz različitih perspektiva koja bi bila podloga za javnu raspravu i kasnije donošenje zakona. Također je potreban, smatra sugovornica iz udruge LET, neki oblik javne kampanje radi senzibiliziranja javnosti za tu temu. 
Sugovornica iz Ministarstva zdravstva pak smatra kako bi, iz perspektive zdravstvene zaštite, u okviru legalizacije "imali mogućnost davati obavezu seksualnim radnicama da se u određenim periodima javljaju ginekolozima i štite i svoje zdravlje i zdravlje svojih klijenata, tako je najjednostavnije". O legalizaciji, iako nije specificirano o kojem tipu legalizacije je riječ, pozitivno se izjašnjava i jedna od dviju sugovornica iz Ministarstva pravosuđa, s određenim ogradama kada je u pitanju kontekst hrvatskog pravosuđa:

Pristala bih na legalizaciju kada bi se posložili uvjeti, ne kako ono kod nas obično stvari idu, "trlj-brlj", pa mi nešto glaziramo i tako ostavimo. Nego da to bude razrađeno na način da stvarno ima opravdana svrha zašto se to legalizira. I da onda krene $\mathrm{u}$ tom smjeru zakonodavstvo i organizacija tog posla tako da se svi negativni elementi koje mi sad srećemo anuliraju. (Ministarstvo pravosuđa)

"Švedski model" najjasnije podržava Pravobraniteljica za ravnopravnost spolova, a zagovara ga i sugovornica iz Ministarstva za demografiju, mlade, obitelj i socijalnu politiku. Tom modelu sklona je i sugovornica iz saborskog odbora (iako je navela, bez dodatnih objašnjenja, kako ne bi išla prema potpunom nekažnjavanju pružatelja seksualnih usluga, što ne bi bilo u skladu s intencijom tzv. švedskog modela). Taj model zagovaraju i stručnjakinje iz udruga B.A.B.E. i Kuća ljudskih prava, iako ne isključuju ni druge modele.

Gotovo sve stručnjakinje koje spadaju u skupinu zagovornika tog modela naglasile su kako je iznimno važno, uz ukidanje kriminalizacije seksualnih radnica i kažnjavanje klijenata, osigurati snažnu potporu sustava ženama koje žele izaći iz prostitucije.

Treba se angažirati sustav koji se bazira na obrazovanju, pomaganju, podršci, pomoći, zdravstvenoj zaštiti, koji bi pomagao tim osobama da se nekako osnaže i pripreme zapravo za drugi rad, da nije samo prostitucija. (Kuća ljudskih prava)

Znači da im se baš osigura i savjetovanja, i pomoć, i podrška, posebno ako se žele prestati time baviti, da im se osiguraju nekakve dodatne edukacije, da ih se dodatno obrazuje, da im se pomogne naći drugo zaposlenje i slično. Znači nismo za potpunu legalizaciju kao što je to na Novom Zelandu, mislim nije ni to opcija koju mi sad potpuno isključujemo, ali da - ne naginjemo tome. (B.A.B.E)

Dakle, mora postojati zamjena teza i zamjena stigme da onaj tko potiče takvu eksploataciju mora biti prokazan i treba biti svjestan da čini kazneno djelo. Dok ne stavimo taj ekvivalent, teško da možemo govoriti o nekakvoj učinkovitosti, dakle, ono što smatramo najvažnijim problemom je takvo zakonsko određenje gdje klijent prolazi kao anonimus. (Pravobraniteljica za ravnopravnost spolova)

Oni koji se odaju prostituciji su žrtve. Njima treba ponuditi ono što švedski model nudi, njima treba pomoć da izađu iz tog začaranog kruga ponašanja. Predložila 
bih zakonski da se odmah - znači odmah - ide u hitnu proceduru, da ih se procesuira i da moraju odmah biti lišeni slobode, odmah... ti klijenti... na klijente isto tako represivno, s velikim kaznama. (Ministarstvo za demografiju, mlade, obitelj i socijalnu politiku)

\subsection{Važnost sudjelovanja širokog spektra stručnjaka i osoba koje se bave seksualnim radom u izradi javnih politika}

Upitani o javnim politikama i tijelima koja bi trebala sudjelovati u kreiranju nekog novog zakona koji bi regulirao prostituciju, sugovornici naglašavaju važnost sudjelovanja širokog spektra stručnjaka i institucija koji bi trebali pokriti različite perspektive $i$ aspekte tog složenog problema.

U kreiranje javnih politika trebale bi biti uključene sve relevantne skupine, pa tako posebice udruge koje se bave ovom problematikom i neovisne institucije koje se bave zaštitom ljudskih prava. (Pravobraniteljica za djecu)

Sugovornica iz Ureda pučke pravobraniteljice ističe kako to nije pitanje samo represivnog sustava te da u stvaranje javnih politika trebaju biti uključeni "nekakvi sustavi podrške i zaštite osoba koje pružaju usluge (...) Čini mi se da je to šira priča od samog MUP-a koji predlaže neka zakonska rješenja.”

Također, svi intervjuirani stručnjaci slažu se oko potrebe da u tom procesu sudjeluju i osobe kojih se to najviše tiče, tj. seksualne radnice i radnici bez kojih je nemoguće do kraja razumjeti brojne dimenzije tog složenog društvenog fenomena.

Važnost sudjelovanja seksualnih radnica/ka posebno naglašava zaposlenica Ureda pučke pravobraniteljice:

Treba pitati osobe koje se time bave, što je ono što njima treba, koja vrsta podrške, zaštite, kako bi ili taj rad bio sigurniji za njih i za njihove obitelji i ne bi ih dodatno stigmatizirao ili, u slučaju da se više ne žele baviti tim radom, na koji način zapravo mogu izaći, koji tip podrške im treba.

Sugovornica iz jednog saborskog odbora smatra kako je prostitucija "jedna od tema gdje je moguće i opravdano jasno učiniti kvalitetniju zakonsku promjenu u smislu pravednijeg društva”.

Zaključno, može se reći da stručnjaci/kinje prepoznaju kako bi bilo dobro da različiti akteri sudjeluju u kreiranju javnih politika te da bi glas osoba koje pružaju seksualne usluge i udruga koje se problemom prostitucije neposredno bave bio važan u oblikovanju politika regulacije prostitucije. 


\section{Rasprava}

Nalazi ukazuju da je prostitucija u Hrvatskoj i dalje tabuizirana i marginalizirana tema. Jedan od indikatora tabuizacije i društveno-političke osjetljivosti teme je i činjenica da su neki od naših ispitanika/ca-stručnjaka/inja, pretežno zaposlenih u državnim institucijama, posebno naglašavali kako inzistiraju na anonimnosti. Tako izražen strah ili nelagoda povezana s mogućnošću da se njihovi stavovi prezentiraju javno ukazuje na to u kojoj mjeri je tema prostitucije u hrvatskom društvu još uvijek kontroverzna i koliko se prije svega povezuje s pitanjem (ne)morala. Da se radi o temi koja može izazvati snažne reakcije, govori i podatak da su neke stručnjakinje iz civilnog sektora odbile sudjelovati u istraživanju s unaprijed formiranom pretpostavkom da će zaključci proizašli iz ovog istraživanja biti u raskoraku s njihovim (radikalno feminističkim) stavovima i vizijama potencijalnih rješenja. Naime, na poziv da se odazove na sudjelovanje $u$ istraživanju, jedna udruga odbila je intervju i poslala odgovor u kojem je insinuirala kako se ovo istraživanje radi s ciljem zalaganja za model legalizacije prostitucije, a sličnu pretpostavku iznijela je i jedna javna institucija, koja je prvotno odbila razgovor o temi, da bi konačno, nakon dodatnih pojašnjenja, intervju ipak bio uspješno proveden.

Analizirajući u prethodnom poglavlju prezentirane podatke, možemo vidjeti da su se stručnjaci iz svih domena složili oko toga da je zakon koji je trenutno na snazi neadekvatan i zastario te da bi ga trebalo mijenjati. Očekivano, njihove primjedbe na zakon reflektiraju različite pozicije iz kojih kritički sagledavaju trenutno zakonsko rješenje, međutim, kao što je već rečeno, gotovo svi su se ispitanici složili kako je kriminalizacija osoba koje pružaju seksualne usluge neprihvatljiva iz niza razloga, a prije svega jer dodatno otežava ionako tešku poziciju tih osoba koje su stigmatizirane i društveno marginalizirane.

Osim što zakon pogoršava težak položaj osoba (prvenstveno žena) na koje se primjenjuje, on je i nedovoljno jasan, što je primijetio predstavnik Ministarstva unutarnjih poslova, koji nije toliko govorio o položaju pružatelja/ica seksualnih usluga koliko o problemu formulacije zakona koji otežava posao policijskim i sudbenim tijelima u procesuiranju. Općenito govoreći, odgovori tog ispitanika većinom su se ticali praktičnih pitanja primjene zakona, a manje teorijsko-ideoloških stavova o prostituciji. Najjasnije razrađene teorijsko-ideološke stavove imale su stručnjakinje iz udruga koje se bave smanjenjem štete i institucija za rodnu ravnopravnost.

Kritika kriminalizacije osoba koje se bave prostitucijom koju su iznijeli sugovornici u skladu je s međunarodnopravnim normama prema kojima se te osobe ne bi trebale kažnjavati. S obzirom na to da se protive kažnjavanju seksualnih radnica/ka, svi su se sugovornici također negativno osvrnuli na prijedloge Zakona o prekršajima protiv javnog reda i mira prema kojem bi se uz osobe koje prodaju seksualne usluge kriminalizirali i klijenti. Pojedini sugovornici zagovaraju kriminalizaciju kli- 
jenata, a pojedini zagovaraju dekriminalizaciju svih strana kod dobrovoljne odrasle prostitucije, što odražava dominantne diskurse o prostituciji kao nasilju i eksploataciji, odnosno seksualnom radu. Ti su dihotomni diskursi prisutni i u dokumentima javnih politika i debatama o toj temi unutar diskursa organizacija civilnog društva i političkog diskursa (Radačić, 2017a; Šipić, Radačić i Baketa, 2021). Podaci dobiveni ovim istraživanjem to potvrđuju. Najveći broj intervjuiranih stručnjaka/inja svoje je stavove elaborirao polazeći od tih dominantnih premisa o prostituciji te od različitog shvaćanja koncepta ljudskih prava. Pojedini akteri jasno su se pozicionirali vezano uz dihotomiju: Pravobraniteljica za ravnopravnost spolova npr. zastupa radikalno feminističku poziciju, prema kojoj su žene u prostituciji uvijek žrtve, dok udruge koje se bave politikama smanjenja štete zastupaju liberalni diskurs prava na izbor, pa tako i u području rada. Dio stručnjaka zaključio je pak kako prostitucija može biti definirana na različite načine i da jedna definicija ne isključuje nužno druge. Pojedini stručnjaci/kinje prostituciju su razmatrali prvenstveno iz perspektive rada njihove institucije - kao javnozdravstveni problem (npr. sugovornica iz Ministarstva zdravlja) ili kao prijetnju javnom redu i miru (npr. sugovornik iz Ministarstva unutarnjih poslova, premda je i on prepoznao razne dimenzije fenomena).

Iako je, dakle, dio stručnjaka/inja prostituciju smatrao kompleksnom pojavom, na kraju su se, s većom ili manjom dozom uvjerenosti, opredijelili za neki od postojećih modela (kriminalizacija klijenata, dekriminalizacija, legalizacija). No, pojedini stručnjaci iz različitih državnih institucija nisu upoznati s mnogim informacijama o tome što pojedini model regulacije prostitucije znači u praksi, kakve su njegove karakteristike, prednosti i nedostaci u zemljama u kojima su implementirani itd. jer je tema prostitucije, osim što je tabuizirana, ujedno i institucionalno zanemarena ili marginalizirana, te se $u$ dokumentima, strategijama i akcijskim planovima prvenstveno povezuje s trgovinom ljudima i seksualnim iskorištavanjem (Šipić, Radačić i Baketa, 2021). Kao što je razmatrano u ovom članku, literatura ukazuje na kompleksnost pojedinih politika i na implikacije različitih modela za ljudska prava osoba koje se bave prostitucijom.

Razlike u razmišljanjima o zakonskoj regulativi, osim iz ideoloških pozicija pojedinih sugovornika/ica, proizlaze i iz specifičnosti profesionalnih pozicija, tj. polazišnih točaka pojedinih struka, pa se tako na primjer intervjuirana osoba iz Ministarstva zdravstva zalaže za legalizaciju prostitucije radi veće zaštite žena, ali i s argumentom da se kroz takav regulatorni model društvo najefikasnije može nositi s problemom javnog zdravlja. Nadalje, iako predstavnik Ministarstva unutarnjih poslova nije iznio jasan stav oko izbora potencijalno najprimjerenijeg regulativnog modela za naš društveni kontekst - naglašavajući pritom potrebu za širokom javnom raspravom - iz pozicije vlastite struke, te uzimajući u obzir pravosudne procedure, kritički se osvrnuo na tzv. švedski model smatrajući ga pravno neefikasnim. 
U skladu s tom perspektivom i u akademskoj literaturi može se naći niz kritika koje ukazuju na to da je jako mali broj osoba koje kupuju seksualne usluge stvarno na kraju i kažnjen jer ih je zbog nedostatka dokaza gotovo nemoguće osuditi (Scoular, 2010).

Kao što smo mogli vidjeti, zagovaranje "švedskog modela" nije prisutno samo među pojedinim stručnjakinjama iz feminističkih organizacija civilnog društva, već i kod neovisne državne institucije za ravnopravnost spolova. Te stručnjakinje problematiziraju pitanje izbora ili izričito zastupaju stav kako je rodno uvjetovano nasilje uvijek u pozadini svakog oblika prostitucije. Takvi se stavovi oslanjaju na teorije radikalnog feminizma koje prostituciju vide kao seksualnu eksploataciju žena, perpetuirano nasilje nad ženama te manifestaciju muške moći i patrijarhalne privilegiranosti muškaraca (Barry, 1997; Kissil i Davey, 2010).

Potpuno drugačiji pristup problemu iskazali su intervjuirani stručnjaci/kinje koji pripadaju organizacijama civilnog društva koje se bave smanjenjem štete te direktno rade s osobama koje prodaju seksualne usluge. To je pristup koji proizlazi iz teorijskih polazišta liberalnog feminizma te podrazumijeva pravo na izbor prostitucije kao legitimnog načina zarade za život, odnosno stav da prostituciju treba tretirati kao bilo koji drugi rad. Najprimjereniji regulatorni zakonski model, prema mišljenju stručnjaka iz te skupine, mora podrazumijevati potpunu dekriminalizaciju odrasle dobrovoljne prostitucije, kao što je to slučaj na Novom Zelandu, dok legalizacijski model, naglašavaju neki, nije riješio probleme, kako se prvotno očekivalo, već ih dodatno generira.

Svi su ispitanici bili zainteresirani za uspostavu politika koje bi omogućile lakši izlazak iz prostitucije s naglaskom na tome da bi o načinima i potrebama pri izlasku trebalo pitati, između ostalih dionika, i osobe koje se prostitucijom bave, što je samo jedan od koraka prema demokratizaciji politika usmjerenih prema prostituciji. Uključivanje osoba koje se bave prostitucijom u donošenje i implementaciju politika regulacije prostitucije zastupaju i udruge za ljudska prava (Amnesty International, 2016).

\section{Zaključak}

Činjenica da je u Hrvatskoj još uvijek na snazi zakon iz 1977. godine i da se radi o izrazito konzervativnom pristupu regulaciji prostitucije, koji podrazumijeva prekršajno (a katkad i kazneno) gonjenje osoba koje prodaju seksualne usluge, govori s jedne strane da se prostitucija još uvijek tretira kao društveno zlo i tabu, a s druge da je interes za javne politike usmjerene prema tom problemu gotovo nepostojeći. Osim nerealiziranih prijedloga izmjene zakona 2012. i 2016 godine, i to u smjeru dodatne kriminalizacije, koja uključuje i klijente, ali i rigoroznije kažnjavanje osoba koje prodaju seksualne usluge, nije bilo javnih rasprava ili ozbiljnijih raz- 
matranja donošenja novih javnih politika koje bi se ticale prostitucije. Iako ovo istraživanje pokazuje kako stručnjaci/kinje prepoznaju potrebu za promjenom zakonodavnog okvira, na marginalizirani status ove teme i njezinih aktera u javnom diskursu dodatno ukazuje i nalaz koji otkriva limitiranost znanja i informacija o prostituciji i oblicima regulacije nekih eksperata koji su zaposleni u relevantnim institucijama za donošenje javnih politika. Institucionalnu nezainteresiranost, ali i zaključak da je ova tema tabuizirana dobro podcrtava i to što dio eksperata, iako dolazi iz državnih tijela poput ministarstava ili saborskih odbora, prezentira svoje osobne, a ne institucionalne stavove. Samo institucije koje se bave rodnom tematikom ili programima smanjenja štete imaju razrađenije stavove prema prostituciji, bilo da je riječ o javnim institucijama ili o institucijama civilnog društva. Glavni je nalaz koji proizlazi iz ovog istraživanja da postoji raskorak između konzervativne i pojednostavljene percepcije prostitucije kao društvenog zla, koja se ogleda u trenutnom vidu regulacije, i stavova ispitanih stručnjaka/inja koji, bez obzira na različite stavove u pogledu prostitucije i zagovaranja poželjnih zakonskih rješenja, gotovo jedinstveno sugeriraju promjenu u smjeru ukidanja prekršajnog i kaznenog progona osoba koje prodaju seksualne usluge.

Među relevantnim kreatorima javnih politika u mnogim razvijenim zemljama Europe diskurs tabuizacije i društvenog zla više nije prisutan, što je razvidno i iz promjena zakonodavnih okvira tijekom posljednjih dvadesetak godina. Utoliko nalazi ovog istraživanja ukazuju na potrebu da se i u našem društvenom kontekstu prostitucija što prije počne redefinirati kroz široku javnu raspravu koja bi, prema stavovima ispitanih stručnjaka/inja, trebala obuhvatiti što je moguće više aktera, uključujući i osobe koje prodaju seksualne usluge. Stavovi ispitanika o ovoj temi relevantni su jer se radi o ekspertima, predstavnicima institucija, koji bi u nekim budućim javnim raspravama trebali biti ključni akteri koji utječu na oblikovanje javnih politika i zakona koji reguliraju prostituciju, ali budući da su neki ispitanici govorili u svoje ime, ostaje nejasno kakav bi bio njihov utjecaj na službene stavove institucija u tim procesima.

\section{LITERATURA}

Abel, G. M. i Fitzgerald, L. J. (2012). “The street's got its advantages": Movement between sectors of the sex industry in a decriminalised environment. Health, Risk \& Society, (14), 1: 7-23. DOI: 10.1080/13698575.2011.640664

Amnesty International. (2016). Policy on State Obligations to Respect, Protect and Fulfil the Human Rights of Sex Workers. POL 30/4062/2016. Dostupno na: https://www. amnesty.org/en/documents/pol30/4062/2016/en/ (pristupljeno 15. srpnja 2021.). 
Aronowitz, A. (2014). To punish or not to punish: What works in the regulation of the prostitution market?, u: Peršak, N. i Vermeulen, G. (ur.): Reframing prostitution. From discourse to description, from moralisation to normalisation?. Maklu. Antwerp: 223-251.

Barry, K. (1997). Prostitution of sexuality: A cause for new international human rights. Journal of Personal and Interpersonal Loss, (2), 1: 27-48. DOI: $10.1080 / 10811449708414404$

Bjønness, J. (2012). Between Emotional Politics and Biased Practices - Prostitution Policies, Social Work, and Women Selling Sexual Services in Denmark. Sexuality Research and Social Policy, (9), 3: 192-202. DOI: https://doi.org/10.1007/s13178012-0091-4

Boyatzis, R. E. (1998). Transforming Qualitative Information. Thematic Analysis and Code Development. Sage. Thousand Oaks, London, New Delhi.

Burchfield, K., Sample, L. i Lytle, R. (2014). Public Interest in Sex Offenders: A Perpetual Panic? Journal of Criminology, Criminal Justice, Law and Society, (14), 3: 96-117.

Burnett, S. (2021). Is a ban on buying sex work effective? Sex workers say 'no'. Dostupno na: https://www.dw.com/en/france-ban-prostitution-sex-workersthreat/a-57198238 (pristupljeno 23. travnja 2021.).

Cho, S., Dreher, A. i Neumayer, E. (2013). Does Legalized Prostitution Increase Human Trafficking?. World Development, (41), 1: 67-82.

Daalder, A. L. (2007). Prostitution in the Netherlands since the lifting of the brothel ban. WODC: deel 249a. The Hague: BJU. Dostupno na: https://publikationen.unituebingen.de/xmlui/bitstream/handle/10900/66769/ob249a_fulltext_tcm45-83466. pdf? sequence=1\&isAllowed=y. (pristupljeno 27. travnja 2021.).

Danna, D. (2014). Report on the Prostitution Policies in the European Union. Università degli Studi di Milano. Milano.

Deana, A. (2019). Nordic Model Now! Prostitution in the EU, or how the lack of legal harmonization goes against the EU's values. Dostupno na: https://www.eu-logos. org/2019/07/29/prostitution-in-the-eu-or-how-the-lack-of-legal-harmonizationgoes-against-the-eus-values/\#_ftn1 (pristupljeno 19. travnja 2021.).

Delacoste, F. i Alexander, P. (1998). Sex work: Writings by women in the sex industry. Cleis Press. Pittsburgh.

Della Giusta, M. i Munro, V.(2016). Demanding Sex: Critical Reflections on the Regulation of Prostitution. Routledge. London. DOI: https://doi.org/10.4324/9781315576374

Europski parlament. (2014). Sexual exploitation and prostitution and its impact on gender equality. Dostupno na: https://op.europa.eu/hr/publication-detail/-/publication/ eaaae1a9-8c4c-11e7-b5c6-01aa75ed71a1/language-hr/format-PDF/source-search (pristupljeno 8. svibnja 2021.). 
Harrington, C. (2012). Prostitution Policy Models and Feminist Knowledge Politics in New Zealand and Sweden. Sexuality Research and Social Policy, (9), 4: 337-349. DOI 10.1007/s13178-012-0083-4

Immordino, G. i Russo, F. F. (2015). Laws and Stigma: the Case of Prostitution. CSEF Working Papers 388. Centre for Studies in Economics and Finance (CSEF), University of Naples, Italy.

IWRAP IP. (2017). Framework on Rights of Sex Workers \& CEDAW. Dostupno na: https://www.iwraw-ap.org/wp-content/uploads/2018/04/Framework-on-Rights-ofSex-Workers-CEDAW-1.pdf (pristupljeno 30. svibnja 2021.).

Jacobsson, P. (2012). "EXIT - from what, why and how?". Nordic network conference, Oslo, 31. 5. 2012. Dostupno na: https://prosentret.no/nordic-network-meeting-inoslo/ (pristupljeno 4. travnja 2021.).

Jeffreys, S. (2008). The Industrial Vagina. The Political Economy of the Global Sex Trade. Routledge. London. DOI: https://doi.org/10.4324/9780203698303

Jutarnji list. (2007). Go-go plesačica u "Temi dana": U tri mjeseca zaradim 100.000 kuna. Dostupno na: https://www.jutarnji.hr/naslovnica/go-go-plesacica-u-temi-dana-u-tri-mjeseca-zaradim-100.000-kuna-3256001 (pristupljeno 12. travnja 2021.).

Jutarnji list. (2012). Vlada o prostituciji. Milanović: "Kazne za klijente prostitutki? To je tek za raspravu!'. Dostupno na: https://www.jutarnji.hr/vijesti/hrvatska/vlada-oprostituciji-milanovic-kazne-za-klijente-prostitutki-to-je-tek-za-raspravu-1351308 (pristupljeno 30. svibnja 2021.).

Kingston, S. i Thomas, T. (2018). No model in practice: a 'Nordic model' to respond to prostitution?. Crime Law Soc Change, (71), 4: 423-439. DOI: https://doi. org/10.1007/s10611-018-9795-6

Kissil, K. i Davey, M. (2010). The prostitution debate in feminism: Current trends, policy and clinical issues facing an invisible population. Journal of Feminist Family Therapy: An International Forum, (22), 1: 1-21. DOI: https://doi. org/10.1080/08952830903453604

Le Bail, H., Giametta, C. i Rassouw, N. (2016). What do sex workers think about the French Prostitution Act?: A Study on the Impact of the Law from 13 April 2016 Against the 'Prostitution System'in France. Research Report Médecins du Monde. Dostupno na: https://hal.archives-ouvertes.fr/hal-02115877/document (pristupljeno 12. travnja 2021.).

Levy, J. i Jakobsson, P. (2014). Sweden's abolitionist discourse and law: Effects on the dynamics of Swedish sex work and on the lives of Sweden's sex workers. Criminology \& Criminal Justice, (14), 5: 593-607.

McClintock, A. (1993). Sex Workers and Sex Work: Introduction. Social Text, 37: 1-10. Dostupno na: www.jstor.org/stable/466255 (pristupljeno 12. svibnja 2021.).

Mossman, E. (2007). International Approaches to Decriminalising or Legalising Prostitution. Ministry of Justice. Wellington. 
Nordic Network. (2012). For Social- and Health Organisations, Sex Workers and Researchers working in The Field of Prostitution. ProSentret. Oslo. Dostupno na: https:// prosentret.no/nordic-network-meeting-in-oslo/ (pristupljeno 2. travnja 2021.).

O'Connell Davidson, J. (1998). Prostitution, Power and Freedom. Polity Press. Cambridge.

O’Neil, M. (2001). Prostitution and Feminism: Towards a Politics of Feeling. Polity Press. Cambridge.

Ostergren, P. (2017). From Zero-Tolerance to Full Integration: Rethinking Prostitution Policies. DemandAT Working paper No. 10. Dostupno na: https://www.demandat.eu/sites/default/files/DemandAT_WP10_ProstitutionPoliciesTypology_June2017_0.pdf (pristupljeno 10. travnja 2021.).

Outshoorn, J. (2005). The political debates on prostitution and trafficking of women. Social Politics: International Studies in Gender, State and Society, 12, (1): 141-155.

Overs, C. i Loff, B. (2013). Toward a legal framework that promotes and protects sex workers' health and human rights. Health and Human Rights Journal, (15), 1: 186196.

Pates, R. (2012). Liberal laws juxtaposed with rigid control: An analysis of the logics of governing sex in Germany. Sexuality Research and Social Policy, (9), 3: 212-222. DOI: $10.1007 / \mathrm{s} 13178-012-0092-3$

Post, C., Brouwer, J. G. i Vols, M. (2019). Regulation of Prostitution in the Netherlands: Liberal Dream or Growing Repression?. The European Journal on Criminal Policy and Research, (25), 2: 99-118. DOI: https://doi.org/10.1007/s10610-018-9371-8

Radačić, I. (2017a). Assessing Prostitution Policies in Europe, u: Økland Jahnsen, S. i Wagenaar, H. (ur.): Assessing Prostitution Policies in Europe. Routledge. London: 217-228.

Radačić, I. (2017b). Prostitution Policy and Practice: Criminalisation Framework, u: Radačić, I. i Pajnik, M. (ur.): Prostitution in Croatia and Slovenia. Sex Workers' Experience. Institute of Social Science Ivo Pilar i The Peace Institute. Zagreb i Ljubljana: 27-37.

Radačić, I. (2017c). New Zealand Prostitutes' Collective - An Example of a Successful Policy Actor. Social Sciences, (6), 2: 1-12. DOI: http://dx.doi.org/10.3390/socsci6020046

Radačić, I. i Antić, M. (2021). Criminalisation of prostitution in Croatia: Rethinking the Public Order. The International Journal of Human Rights (u postupku objavljivanja).

Radačić, I. i Pajnik. M. (ur.). (2017). Prostitution in Croatia and Slovenia. Sex Workers' Experience. Institute of Social Sciences Ivo Pilar i The Peace Institute. Zagreb i Ljubljana.

Radulović, D. (1986). Prostitucija u Jugoslaviji. Zavod za izdavačku delatnost "Filip Višnjić". Beograd. 
Randers-Pehrson, A. i Misje, T. 2012. Introduction. Summary from Nordic Network meeting. Dostupno na: https://prosentret.no/publikasjoner/pro-sentrets-reports-inenglish/ (pristupljeno 18. travnja 2021.).

Sanders, T. (2006). Sexing Up the Subject: Methodological Nuances in Researching the Female Sex Industry. Sexualities, (9), 4: 449-468. DOI: https://doi. org/10.1177\%2F1363460706068044

Scoular, J. (2010). What's Law Got to Do with it? How and Why Law Matters in the Regulation of Sex Work. Journal of Law and Society, (37), 1: 12-39.

Sex Worker Forum. (2017). Shadow Report to the United Nations Committee on the Elimination of Discrimination against Women, Sixty-sixth session, 13 February 3 March 2017, Concerning the Seventh and Eighth Periodic Reports of Germany. CEDAW - UN Committee on the Elimination of Discrimination Against Women. Dostupno na: https://tbinternet.ohchr.org/Treaties/CEDAW/Shared\%20Documents/ DEU/INT_CEDAW_NGO_DEU_26287_E.pdf (pristupljeno 30. travnja 2021.).

Specijalni izvjestitelj o pravu na zdravlje. (2010). Izvješće za 2010. UN.Doc.A/ $\mathrm{HRC} / 14 / 20$.

SWAN. (2019). Sex Work Legal Framework in Central-Eastern Europe and Central Asia. SWAN. Budimpešta. Dostupno na: https://swannet.org/resources/sex-worklegal-frameworks-in-ceeca/ (pristupljeno 27. travnja 2021.).

Šipić, J., Radačić, I. i Baketa, N. (2021). Politike prostitucije u Hrvatskoj: kritička analiza okvira. Društvena istraživanja (tekst prihvaćen za objavljivanje).

Štulhofer, A., Baćak, V., Drglin, T., Puljiz, M. i Miklin, M. (2009). Female Sex Workers and HIV Risks in Croatia. AIDS Care, (21), 11: 1439-1446.

Štulhofer, A., Landripet, I., Božić, J. i Božiković, I. (2015). HIV Risks and HIV Prevention Among Female Sex Workers in Two Largest Urban Settings in Croatia, 20082014. AIDS Care, (27), 6: 767-771.

Štulhofer, A., Sinković, M., Božić, J. i Baćak, V. (2016). Victimization and HIV Risks Among Croatian Female Sex Workers: Exploring the Mediation Role of Depressiveness and the Moderation Role of Social Support. Violence against women, (23), 1: 67-88. DOI: $10.1177 / 1077801216636241$

Terry, G., Hayfield, N., Clarke, V. i Braun, V. (2017). Thematic analysis, u: Stainton, W. i Willig, C. (ur.): The SAGE Handbook of Qualitative Research in Psychology. SAGE Publications. London: 17-37.

Tertinegg, K., Hrzenjak, M. i Sauer, B. (2007). What's the problem with prostitution? Prostitution politics in Austria and Slovenia since the 1990s: A comparison of frames, u: Verloo, M. (ur.): Multiple Meanings of Gender Equality: A Critical Frame Analysis of Gender Policies in Europe. Central European University Press. Budimpešta: 187-206.

Valadier, C. (2018). Migration and Sex Work through a Gender Perspective. Contexto Internacional, (40), 3: 501-523. 
Wagenaar, H. i Altnik, S. (2012). Prostitution as Morality Politics or Why It Is Exceedingly Difficult to Design and Sustain Effective Prostitution Policy. Sexuality Research and Social Policy, (9), 3: 279-292. DOI: 10.1007/s13178-012-0095-0

Weitzer, R. (2012). Legalizing prostitution: from illicit vice to lawful business. New York University. New York, London.

UN Special Rapporteur on the right of everyone to the enjoyment of the highest attainable standard of physical and mental health. (2010). Report to the General Assembly. UN. Doc. A/65/255. t. 36-37.

UN Working Group on Discrimination against Women and Girls. (2016). Report on health and safety, A/HRC/32/44, t. 84.

UN Working Group on Discrimination against Women and Girls. (2018). Dostupno na: https://www.ohchr.org/en/issues/women/wgwomen/pages/wgwomenindex.aspx (pristupljeno 15. travnja 2021.).

Županov, J. (2002). Od komunističkog pakla do divljeg kapitalizma. Odabrane rasprave i eseji (1995-2001.). Hrvatska sveučilišna naklada. Zagreb.

Rašeljka Krnić, Mirjana Adamović, Ivana Radačić

\title{
ATTITUDES OF EXPERTS ON THE POLICY OF PROSTITUTION REGULATION IN CROATIA
}

\begin{abstract}
Summary
Different ideological positions determine models or policies aimed at regulating prostitution, respectively persons who engage in prostitution, organize prostitution or seek services in that domain of social life. In this paper, we present the views of relevant experts on prostitution policies in the Republic of Croatia. The conclusions of the paper are based on a qualitative research conducted in semi-structured interviews on a sample of 15 experts from different fields (ministries, government offices, independent state bodies, parliamentary committees and civil society organizations) in whose scope of regulation is the phenomenon of prostitution or related problems. Interviewees most often place prostitution either in the discourse of violence and exploitation or sexual labor. Most experts advocate a change in the model of regulation of prostitution, and among the most frequently mentioned European models, which the Croatian model could be modeled on, are the Swedish model of criminalization of clients, the decriminalization model and the model of legalization. It is noticeable that civil society professionals who devise harm reduction programs and work with people who sell sexual services are more likely to opt for liberal models of regulating prostitution. All experts emphasize the importance of adopting policies that would make it easier to get out of prostitution.
\end{abstract}

Keywords: Prostitution, Models of Prostitution Regulation, Public Policies, Human Rights 
Rašeljka Krnić je znanstvena suradnica na Institutu društvenih znanosti Ivo Pilar. Mirjana Adamović je viša znanstvena suradnica na Institutu za društvena istraživanja u Zagrebu.

Ivana Radačić je znanstvena savjetnica na Institutu društvenih znanosti Ivo Pilar.

Kontakti:

Rašeljka Krnić, Institut društvenih znanosti Ivo Pilar, Trg Marka Marulića 19, 10000 Zagreb. E-mail: raseljka.krnic@pilar.hr

Mirjana Adamović, Institut za društvena istraživanja, Frankopanska 22, 10000 Zagreb.E-mail:mirjana@idi.hr

Ivana Radačić, Institut društvenih znanosti Ivo Pilar, Trg Marka Marulića 19, 10000 Zagreb. E-mail: ivana.radacic@pilar.hr 